\title{
CONCEPTUALISING AND OPERATIONALISING WORK VERSUS CAREER SALIENCE
}

\author{
STUART ALLEN \\ KAREN ORTLEPP \\ Department of Psychology, \\ University of the Witwatersrand
}

\begin{abstract}
Career salience was defined and operationalised by Greenhaus in 1971. His scale and conceptualisation of this construct have attracted critical review. Numerous authors have tested various alternative conceptualisations of career salience. However, these approaches have tended to neglect some of the valuable ideas in Greenhaus' original construct. The present authors suggest that career salience constructs and measures have also been contaminated with an associated but unrecognised construct, namely, work salience. In this study, new work and career salience scales were developed and validated on a sample of 1078 office workers. The data supported the independent definition and measurement of work salience.
\end{abstract}

\section{OPSOMMING}

Loopbaanmarkantheid is in 1971 deur Greenhaus gedefinieer en geoperationaliseer. Sy skaal en konseptualisering van hierdie konstruk het kritiese kommentaar ontlok. Menige skrywers het verskeie alternatiewe konseptualiserings van loopbaanmarkantheid getoets. Hierdie benaderings is egter geneig om sommige van die waardevolle idees van Greenhaus se oorspronklike konstruk te verwaarloos. Die teenswoordige outeurs suggereer dat loopbaanmarkantheidkonstrukte en -maatstawe deur ' $n$ geassosieerde en minder, bekende konstruk, naamlik werkmarkantheid gekontamineer word. In hierdie studie is nuwe werk- en loopbaanmarkantheidskale ontwikkel en gevalideer op ' $n$ steekproef van 1078 kantoorwerkers. Die data ondersteun die onafhanklike definisie en meting van werkmarkantheid.

Almost 28 years ago Greenhaus (1971, p. 210) introduced the concept of career salience as "the importance of work and a career in one's total life." With this new construct he presented his Career Salience Scale which he has since used extensively in publishing a number of articles predominantly in the study of vocational psychology (e.g. Beutell \& Greenhaus, 1982; Greenhaus, 1974; Greenhaus \& Simon, 1976, 1977; Greenhaus \& Sklarew, 1981). In more recent years, Greenhaus' construct and scale have become the target of a number of valid and important criticisms (Morrow, 1983, 1993). Besides the essential work of Greenhaus, a number of other authors have produced scales that test similar or related constructs (e.g. Amatea, Cross, Clark \& Bobby, 1986; Blau, 1985; Kanungo, 1982). Many of the recent constructs and measures, which have emerged in reaction to the need for new definitive research in the area of work and career salience have focused upon specialised areas of the constructs, and it is the present authors' opinion that they have failed to capture much of the value in Greenhaus' (1971) original construct which identified a very basic disposition to the general concept of work and a career. In addition, despite Greenhaus' (1971) original definition having included reference to the importance of work and careers, the issue of work salience has largely been ignored in psychological literature. Indeed, Roodt (1997) argued that researchers in this field have neglected to build on existing theories and approaches to operationalisation resulting in this field evolving in a fragmented manner. The present study can be seen as attempt to build on and extend pioneering work in this field. An awareness of the importance of work and careers within employees' lives may contribute a great deal to our understanding of employee behaviours and attitudes as related to their motivation and performance. More specifically, a re-conceptualisation and re-operationalisation of career and work salience may facilitate researchers' further exploration of key areas in occupational psychology. Research into topics related to the interface between the home-work environments, the role of career and work salience in the changing world of work, as well as career development issues at different stages of an individual's lifespan, may all be extended and enriched by a re-conceptualisation and a re-operationalisation of these key constructs.

Requests for copies should be addressed to: K Ortlepp, Wits Business School, PO Box 98, Wits, 2050
Greenhaus' Career Salience Scale (CSS)

The items of Greenhaus' CSS were developed to measure the three areas he saw to represent career salience: a) general attitudes toward work, for example, "Work is one of those necessary evils."; b) planning and thinking about a career, for example, "Planning for a specific career is usually not worth the effort."; and c) the relative importance of work and a career, for example, "I intend to pursue the job of my choice even if it cuts deeply into the time I have for my family." (Greenhaus, 1971, p. 211). The first 27 items of the CSS take the form of statements, to which participants may respond on a 5-point Likert-type scale ranging from 'strongly agree' to 'strongly disagree'. The 28th item specifies six areas of life that respondents must rank according to their priority in terms of their importance within the respondent's life. More recent research attempts by Greenhaus have tended to exclude the 28th ranking item (Greenhaus \& Sklarew, 1981). These areas are: "family, career, religion, leisure time, local community activity, national political activity." (Greenhaus, 1971, p. 211). Greenhaus did not actually attempt any form of factor analysis or validation in this first article, and only makes mention of the psychometric property of internal reliability, noting that the CSS achieved an internal reliability coefficient of alpha $=0,81$.

Greenhaus (1973) published a factor analysis of the items of the CSS two years later in an attempt to understand the underlying dimensions of this new construct. The factor analysis produced 3 factors accounting for a total of $27 \%$ of the variance explained. These three factors were identical to the original 'areas' he suggested to make up career salience (Greenhaus, 1971). A 6-item short form of the CSS was later introduced by Greenhaus and Simon (1977) which has been well-used in psychological research (Aryee \& Tan, 1992; Morrow, 1983; Morrow, Eastman \& McElroy, 1991; Noe, Noe \& Bachhuber, 1990; Shore, Thornton \& Shore, 1990). Interestingly, Greenhaus and Sklarew renamed the Career Salience Scale the 'Work Role Salience Scale' in 1981, as they note, the word 'career' connotes a lifetime experience whereas the CSS deals with something more current and temporal.

A number of researchers have made use of Greenhaus' (1971) scale. Internal reliabilities for the 27 -item version have ranged from 0,74 (Greenhaus \& Sklarew, 1981) to 0,90 (Beutell \& 
Greenhaus, 1982). The 6-item short form has achieved internal reliability coefficients of between 0,54 (Morrow \& McElroy, 1986) and 0,83 (Greenhaus \& Simon, 1977). A South African study using the 27 - item version achieved an internal reliability coefficient of 0,70 (Allen \& Ortlepp, 2000). However, it is a reality that longer scales have higher reliabilities (Rosenthal \& Rosnow, 1991). Allen and Ortlepp (2000) and Karim (1997) both achieved coefficient alphas for the subscales ranging from 0,50 to 0,64 . This provides some evidence that with the effect of the large item pool removed, the CSS subscales achieve lower internal reliabilities. Lack of internal consistency reliability is an indication that a scale is measuring content of a heterogeneous nature or multiple constructs. This is undesirable when a scale is supposed to test a single construct.

Blau, Paul and St. John (1993) and Morrow and McElroy (1986) have included the items from the CSS in factor analyses. Both sets of authors mixed the CSS items with items from various other work commitment instruments.

In both factor analyses of the CSS, items loaded onto more than four different factors. The items did load onto factors that they should have, but in most cases the items loaded weakly on these factors or loaded almost equally onto multiple factors. This is further evidence that the CSS does not measure a homogeneous construct. It is also evidence that the discriminant validity of the CSS is low and the redundancy moderately high, in terms of the scales the CSS was analysed with. Morrow (1993) notes that there is little evidence of the scale's construct validity and studies generally show the discriminant validity of the CSS to be especially low (Morrow \& McElroy, 1986; Shore et al., 1990; Wiener \& Vardi, 1980).

The reality of Greenhaus' operationalisations of his career salience construct is that it is more accurately reflected by the alternate definition, "the perceived importance of work in occupational choice and satisfaction," (Stumpf \& Lockhart, 1987, p. 260) than by his original definition. While few authors have criticised Greenhaus' (1971) definition of career salience, a number of authors (Amatea et al., 1986; Blau, 1985; Morrow, 1983, 1993; Morrow, Eastman \& McElroy, 1991) have criticised his operationalisations of this construct and the lack of congruence between the definition of career salience and items of the CSS, indicating poor construct validity. Morrow (1983) is the only author to directly criticise Greenhaus' definition of career salience, suggesting that it is ambiguous and unclear. In agreement, the present authors would suggest that while Greenhaus' definition is simple and handy, a more discriminating and involved definition is required. It is important to place this critical review of Greenhaus' sentient and valuable work in context as almost 30 years have passed since the start of this research and the re-examination and refinement of Greenhaus' original work is a natural developmental process.

The content of many of the CSS items overlap with that of other work commitment scales and frequently includes content beyond the focus of Greenhaus' (1971) original definition. Some of the constructs the CSS is seen to share content with (Morrow, 1983, 1993) include: job involvement (Lodahl \& Kejner, 1965); central life interests (Dubin, 1956); the Protestant Work Ethic (Blood, 1969); and organisational commitment (Mowday, Steers \& Porter, 1979). Examples of this include the CSS short form's correlation with: job involvement, ranging from $r=0,37$ (Wiener \& Vardi, 1980) to $\mathrm{r}=0,62$ (Morrow \& McElroy, 1986); organisational commitment ranging from $\mathrm{r}=0,36$ (Shore et al., 1990) to $r=0,44$ (Aryee \& Tan, 1992; Allen \& Ortlepp, 2000); central life interests at $\mathrm{r}=0,46$ (Morrow \& McElroy, 1986); and Protestant Work Ethic at $\mathrm{r}=0,33$ (Morrow \& McElroy, 1986). Although redundancy is only indicated where correlations exceed $\mathrm{r}=0,60$ to $\mathrm{r}=0,80$ (Morrow, 1983), these correlations highlight that the CSS overlaps in at least some of the content it measures with these other scales. Many of these scales test similar or related constructs, and, therefore, significant covariance is expected and needed (convergent validity). However, the high correlation between the CSS and job involvement is a concern as these are conceptually different constructs and the correlation does not reflect this.

An additional problem with the development and use of the CSS is that it has predominantly been used on student samples as students may not be able to provide meaningful or accurate answers to some of the questions relating to work, holding a job, or having a career. A final issue worth mentioning is Greenhaus' frequent use of mixed and inappropriate referents in his items and in the naming of the CSS subscales (Blau et al., 1993). For example, the first subscale is said to test the relative importance of work and a career, however the words 'work' and 'career' refer to different experiences and may inspire different attitudes. In addition, each of the items of the CSS includes one of the following terms: work, job or career. The present authors would argue that these are different areas of one's occupational life and the incorrect use of these referents may elicit an inappropriate response, which may partly explain the lack of internal reliability and discriminant validity in the CSS.

Although the CSS received considerable attention in its early years, the scale and its construct have received considerably less attention and application since Morrow's (1983) comprehensive critique of measures of work commitment. There is undoubtedly little future for Greenhaus' operationalisations of career salience in future work commitment research (Morrow, 1993).

\section{Concept redundancy}

Much of the recent research on career and work orientation has been done in the area of career commitment and some valuable points can be drawn from this research. However, it is important to note a problematic issue that has arisen in this area of study. Following Morrow's (1983) influential paper on the redundancy of work commitment constructs, a number of new work commitment constructs and measures have been developed (Blau, 1985; Blau et al., 1993; Morrow \& Goetz, 1988; Morrow \& Wirth, 1989). What is difficult about these instruments is that authors tend to view career commitment as a refined conceptualisation of what Greenhaus' (1971) career salience construct dealt with.

Blau (1985) suggested that a new operationalisation and conceptualisation of career commitment would overcome the redundancy of Greenhaus' scale with other constructs such as organisational commitment and job involvement. In line with this suggestion, Blau (1985, p. 280) developed his own career commitment scale, defining career commitment as "one's attitude towards one's profession or vocation." Typical items include, "If I could get another job different from being a nurse and paying the same amount, I would probably take it." and "I spend a significant amount of personal time reading nursingrelated journals or books." (Blau, 1985, p. 280). These items seemingly investigate the importance of being in a specific profession, which is different than career salience, which looks at the importance of a career within a broader life perspective where the nature or type of career is not specified.

Morrow (1993) also tends not to see a clear distinction between career salience and the career/professional commitment constructs as she often expresses that professional and career commitment are refined and developed conceptualisations of career salience. Professional commitment or professionalism does not enjoy a unified definition, but Morrow and Wirth (1989, p. 40) suggest that professional commitment may be defined as "the relative strength of identification with and involvement in one's profession." Morrow and Wirth (1989) evaluated a measure of professional commitment that was based upon Mowday et al.'s (1979) Organizational Commitment Questionnaire, where the word 'profession' was substituted for 'organisation'. Morrow and Goetz (1988) also attempted to evaluate a modified version of Hall's (1968) measure of 
professionalism. However, more recently Morrow (1993) commented that career commitment constructs and specifically Blau's (1985) career commitment scale were perhaps better areas of research as professionalism is a narrow construct lacking generalisability to broader working populations.

Career salience and career/professional commitment are argued by the present authors to be clearly different constructs. Career commitment deals with the commitment to a career or profession, whereas career salience deals with the relative importance of work and a career within the individual's total life. Arguing about the semantics of definitions and construct nomenclature is unlikely to definitively illustrate that these constructs are independent. However, there is also some empirical evidence that these constructs are distinct. A study of women's career orientations by Marshall \& Witjing (1982) illustrated the independence of the commitment and salience constructs. In testing a number of established career orientation scales together (including Greenhaus' (1971) Importance of Work subscale) and then factor analysing the results, they found two central factors to exist. The first factor was called 'career centredness', which is said to describe "an intention to give priority to pursuing and deriving greater satisfaction from one's career over other life activities." (Marshall \& Witjing, 1982, p. 143) and can be likened to career salience. The second factor, labelled career commitment, was said to describe, "the intention to be persistently involved in one's career throughout life, despite lack of financial need or presence of child-rearing obligations." (Marshall \& Witjing, 1982, p. 143). In this way the descriptions of these two factors illustrate most of the important differences between career commitment and career salience.

In their development and testing of a model of career commitment, Aryee and Tan (1992) found that career salience is a significant predictor of career commitment, where the standardised path coefficient was $0,45(\mathrm{p}<0,01)$. This study also found a correlation of $r=0,34(p<0,01)$ between career salience and career commitment. Should these constructs be redundant a correlation of $\mathrm{r}=0,60$ or higher would have been expected (Morrow, 1983). A study by Hoelter (1983) on role identity salience also found support for the notion that role salience and role commitment are separate constructs and reported that salience of a role precedes commitment to that role. Based on Vroom's Expectancy Theory (VIE Theory)(Kreitner \& Kinicki, 1995) the present authors would suggest that commitment to a career would require that the career be important, and essentially more important than other life roles, hence, reinforcing that salience is independent from and precedes commitment. While a person's work or career may be valued or salient, commitment may not always follow, as other life roles may be more important or more expectantly satisfying. A final comment must be made here with regards the theoretical distinction between career salience and career commitment regarding their focus in terms of work and careers. Career salience clearly deals with a more abstract, long term and nonspecific notion of a career and denotes an element of comparison between life roles, examining attitudes about the importance of having a career amongst other competing life roles. Career commitment, however, isolates the attitudes towards a current specific career or profession without suggesting any comparison with other life roles. Nonetheless, it is fairly likely that a certain amount of overlap will always exist between measures of these constructs as they deal with related issues and even the most sensitive instruments will struggle to perfectly isolate each attitude. In support of this contention, Roodt (1997, p. 12), in a South African study, found that "there is no theoretical reason to distinguish between the foci 'work', 'job', 'occupation', 'career' and 'organisation'”. However, the present authors would argue that the constructs of work and career deal with a qualitatively different orientation toward work, and each must be developed for its own unique potential role in psychology.
Although researchers have, over time, begun to distinguish between career-, organisational- and job-related attitudes, very little study has been directed at differentiating work, as a general concept, from these other occupational referents. The Protestant Work Ethic (Blood, 1969) and Work Involvement (Kanungo, 1982) are two of the few constructs that independently make reference to the generalised issues of work. In light of the shortcomings of existing conceptualisations of career salience, the present authors propose the separation of work salience as a separate construct from career salience. This signifies a movement away from previous approaches that have dealt with the issue of career salience alone, or as Greenhaus (1971) has done, mixed the career and work salience constructs. Two issues motivate this change: a) the lack of homogeneity in the CSS resulting from mixing work, job and career-related referents (and, thereby, attitudes); and b) the lack of recognition that attitudes to work may vary separately from attitudes to a career.

An important distinction must be made between Work Salience, the Protestant Work Ethic (Blood, 1969) and Work Involvement (Kanungo, 1982) as these may be construed to be similar constructs. The Protestant Work Ethic considers the "extent to which a person believes in the importance of work itself." (Morrow, 1993, p. 1) and implies a moral or value-related belief which is said to be socialised or conditioned. Work Involvement is as Morrow (1993) notes, in many ways similar to this Protestant Work Ethic, having only a more specific focus with less emphasis on the moralistic view of work as good and integral to a successful life. Both the Protestant Work Ethic scale and the Work Involvement Questionnaire have a clear workvalues focus, where the concept of 'importance' is used as a moral and value-related referent. This is the key difference between the presently proposed construct Work Salience and these two existing constructs as Work Salience does not examine how important the individual thinks work is or should be to people. Instead, Work Salience looks at the actual personal significance and prominence of work as a part of a person's own life relative to other activities.

\section{Construct conceptualisation in the present study}

The present research endorses Greenhaus' $(1987$, p. 6) definition of a career as "the pattern of work-related experiences that span the course of a person's life." Using this understanding of careers, Career Salience [CS] is defined as the relative prominence and personal significance of a career within the individual's total life. This definition is largely a more intricate version of Greenhaus' (1971) definition, excluding the word 'work' and replacing 'importance' with 'prominence and personal significance', which was inspired by Amatea et al. (1986), implying a more affective response. The word 'relative' implies a comparison between various life roles.

Kabanoff (1980, p. 67) specifies that, "Work refers to the set of prescribed tasks that an individual performs while occupying a position in an organization." While some authors (e.g. Fisher, 1987) have defined work in terms of being any activity that involves the expenditure of energy, this fails to separate work from leisure and, hence, the present authors use Kabanoff's definition as it describes what is implied by the word 'work' in the common occupational sense. However, Kabanoff describes an organisation as a body in which it is understood that monetary rewards are exchanged for services. This, of course, would exclude voluntary or unpaid work. Thus, in the present research an organisation is seen to include any body or relationship in which it is understood that rewards are exchanged for services, where rewards may be extrinsic, for example pay, or intrinsic, for example altruistic need fulfilment. This generalised notion of work is not attached to any specific organisation, job, skill or knowledge. The meaning of work has a fairly 'common sense' nature, and as Kabanoff (1980, p. 68) notes "In general, work is a spatially, temporally, and, to an extent, socially discrete well-defined role that we have little trouble identifying." Work Salience [WS] is then simply defined 
as the relative prominence and personal significance of work in an individual's total life.

Morrow (1983) notes that the majority of work commitment research has focused upon five key areas: (a) value focus, (b) career focus, (c) job focus, (d) organisation focus, and (e) union focus. A work focus is clearly absent. Greenhaus' (1971) conceptualisation of CS did include elements of WS, but he always referred to salience of work and careers as a single construct. Dubin's (1956) Central Life Interests, Kanungo's (1982) Work Involvement Questionnaire, and Blood's (1969) Protestant Work Ethic also captured some of the basic notions of WS. Hence, the conception that individuals may have a unique attitude to work and a career is not completely new.

The obvious differences in the definitions of the words 'work' and 'career' illustrate that the primary difference between WS and CS in that CS investigates the importance of a specific longterm pattern of employment possibly attached to a skill, knowledge or an organisation, while WS deals simply with the importance of working or being occupied. In support of this assertion, Kanungo (1982) uses a similar argument in explaining the difference between work and a job or career, stating that work has a generalised context while a job or career has a specific or particular context. In addition, as an example of these constructs' independence, an unemployed or retired professional may forego his/her professional status in order to find paying work, indicating higher WS, or in the case of the unskilled or semi-skilled worker, having a career may be unimportant relative to the importance of having work alone. Lobel and St. Clair (1992) also add their support to this notion in stating that individuals frequently seek relatively undemanding jobs to allow for other effort-intensive activities such as household, childcare and leisure interests, leaving demanding careers behind. Two new scales were developed for the operationalisations of Career and Work Salience. These scales were called the Career Salience Questionnaire [CSQ] and the Work Salience Questionnaire [WSQ] to differentiate them from previous studies.

While support has been developed from the literature for the present research, it must be reinforced that the present research was partially exploratory. The following hypotheses are posed in the present research: The CSQ and WSQ a) will appear to possess face validity, b) will be internally consistent, c) will have a moderately strong positive correlation with each other, d) will emerge as two separate factors in a factor analysis, e) will demonstrate convergent validity when correlated with Greenhaus's (1971) CSS, f) will demonstrate discriminant validity when correlated with the Organizational Commitment Questionnaire (Mowday et al., 1979) and the Job Involvement Questionnaire (Kanungo, 1982), with which it should not theoretically correlate, and g) the CSQ, WSQ, Organisational Commitment Questionnaire, and Job Involvement Scale will each load onto a separate factor in factor analysis, indicating discriminant validity.

\section{METHOD}

\section{Subjects and procedure}

Two questionnaires were constructed, called the Career Salience Questionnaire and Work Salience Questionnaire respectively, from a combination of existing items from previous scales in the area as well as some new items. The items were selected or adapted from existing scales or new items were created to match content domains of the new scale's definitions. Items were selected or created to minimise potential redundancy with other commitment concepts. These items were also scrutinised for face validity as part of a pilot study with a sample of teachers $(\mathrm{N}=$ 23). Three psychologists with demonstrated expertise in this field, examined the content validity of the items. See Tables 1 and 2 for the final items and their references.
The following introduction was included in the instructions for the WSQ:

"The following statements have been designed to make you think about the importance of work in our life. Respond to these statements in terms of your feelings about work as a general concept, not in terms of your present job or any specific job you have had. In these statements work is discussed in terms of working for an organisation and does not include hobbies or housework."

The following introduction was included in the instructions for the CSQ:

"The following statements have been designed to make you think about the importance of having a career in your life. Respond to these statements in terms of your feelings about having a career as being a specific or planned pattern of work over your entire lifetime, rather than in terms of jobs you have at the present or jobs you have had in the past."

TABle 1

WSQ ITEMS AND SOURCES

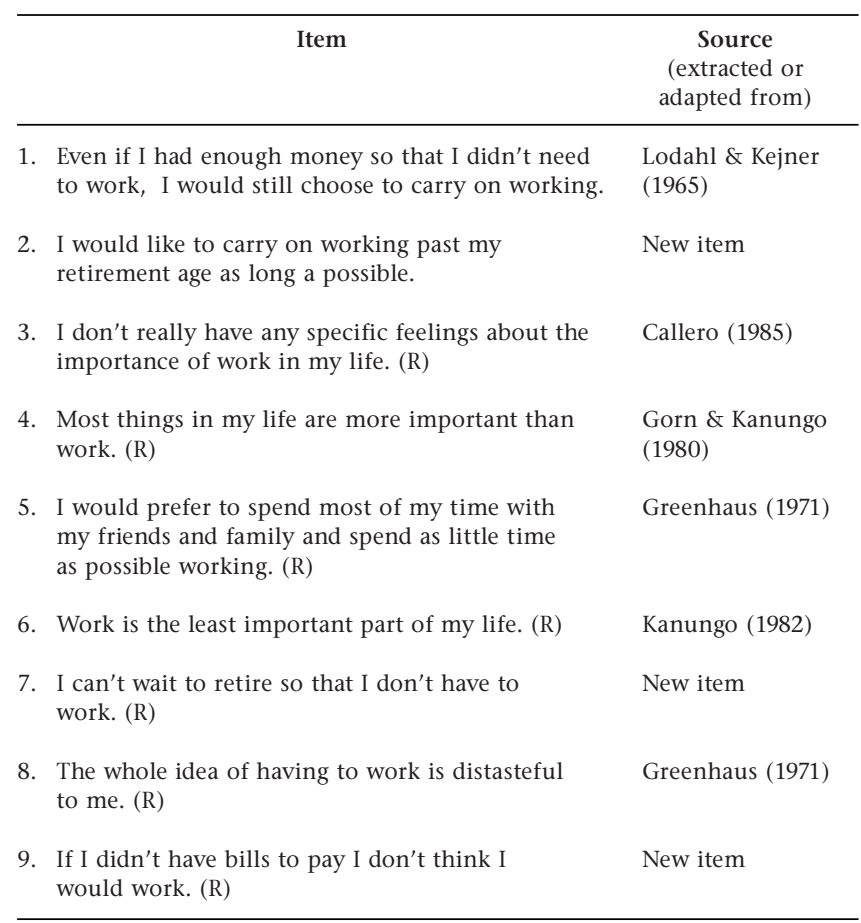

(R) - Indicates items reversed.

TABLE 2

CSO ITEMS AND SOURCES

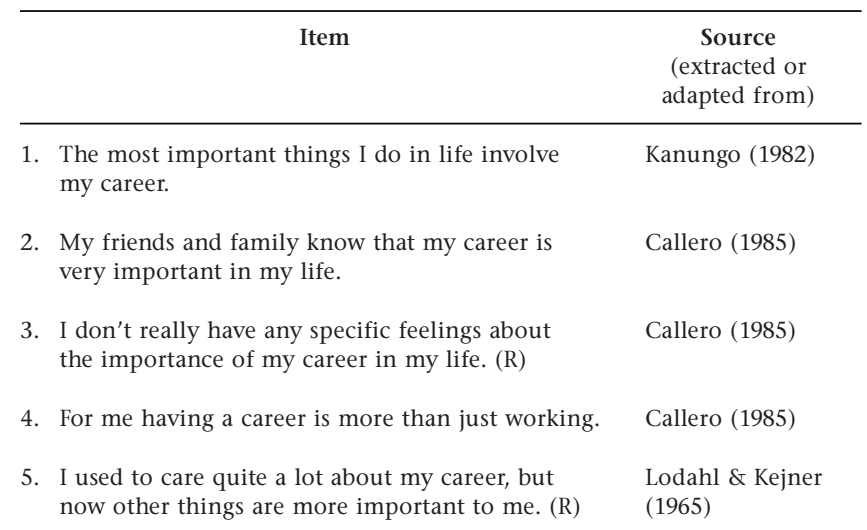


6. I want to work, but I don't want a demanding career. (R)

7. I am willing to make sacrifices in my personal life to succeed in my caree

8. Choosing a career was one of the most important decisions I ever made.

9. My family and my career are both significant parts of my life, but my career tends to be more important.

10. I am willing to make sacrifices in my family life to succeed in my career.
Amatea et al.

(1986)

Amatea et al.

(1986) and

Greenhaus (1971)

Greenhaus (1971)

Lobel \& St Clair (1992)

Based on Amatea et al. (1986) and Greenhaus (1971)

Kanungo (1982)
Employees of a large medical insurance administration organisation were then approached to participate in the study. Questionnaires, explaining the nature of the study and requesting involvement, were circulated to branches throughout South Africa which. A total of 1565 staff were requested to participate, of which 1079 confidentially completed questionnaires were returned $(69 \%$ of 1565) in sealed envelopes. Two types of questionnaires were distributed. Firstly, 400 longer questionnaires were distributed with Greenhaus' (1971) CSS, in order to measure concurrent validity. Secondly, 1165 shorter questionnaires were distributed with Greenhaus' (1971) questionnaire excluded. The two versions were motivated by the need to save costs and to ensure that the majority of the participants had a shorter questionnaire to complete, potentially increasing the return rate. 139 (34.8\% of 400) of the longer form questionnaires were returned complete, while 940 ( $81 \%$ of 1165$)$ of the shorter questionnaires were returned complete. The demographics of the entire sample were: a) 833 (77\%) female, 244 (22\%) male; b) age ranged from 17 to 73 years, with a mean of 32,87 years $(\mathrm{SD}=9,55)$; c) $893(82 \%)$ had 12 years of schooling, 175 (16\%) had less than 12 years of education, $406(38 \%)$ of these individuals had some form of tertiary education; d) 846 (78\%) were general workers, clerks or secretaries, 183 (17\%) were supervisors or department managers, and 38 (4\%) were senior managers; e) 539 (50\% were married; f) $652(60 \%)$ had one or more children; and g) 496 (46\%) spoke English as their home language; 312 (29\%) spoke Afrikaans as their home language, 248 (23) spoke an African language as their home language, and 17 (2\%) spoke an Indian language as their home language. The official language of the organisation was English and all correspondence in the organisation was conducted in English. Accordingly, the present research was conducted in English. No statistically significant differences $(p<0,05)$ were found between the demographics of the individuals who completed the short and long versions of the questionnaires.

\section{Measuring instruments}

Greenhaus' (1971) 27- item Career Salience Scale was used in the present research in order to assess convergent validity. The present research attained a Cronbach alpha for this scale of $0,85(n=130)$ for the total scale, and alphas of $0,68,0,60$ and 0,77 for the respective subscales: a) relative importance of work and career, b) planning and thinking about career, and c) general attitudes to work.

Kanungo's (1982) 10-item Job Involvement Questionnaire was used to measure job involvement for the purposes of demonstrating discriminant validity of the new scales. This scale is largely based upon Lodahl and Kejner (1965) well-known job involvement measure, but is considered a purer measure (Blau, 1985). Responses to the items are recorded on a 5-point response scale. Previous Cronbach alphas for this scale have generally exceeded 0,74 . The present study achieved a Cronbach alpha of $0,84(\mathrm{n}=1036)$.

Organisational commitment was measured using Mowday, Steers and Porter's (1979) 15-item Organizational Commitment
Questionnaire. Responses were recorded on a 5-point response scale. Morrow and McGinnis (1990) report that substantial evidence has been generated in numerous studies supporting the reliability and validity of this scale. The present study achieved a Cronbach alpha of $0,89(n=1001)$.

The new scales, namely the Career Salience Questionnaire and Work Salience Questionnaire, developed in the present research were included with responses being recorded on a 5-point response scale, as with all other scales, ranging from 'strongly disagree' to 'strongly agree' with a midpoint of 'neutral'. The following text will enter in a discussion of the emerging properties of these scales.

\section{RESULTS AND DISCUSSION}

Reliability and descriptive statistics

The final 11- item CSQ and 9- item WSQ are described in Table 3 in terms of their properties and internal consistency reliabilities.

TABLE 3

SCALE PROPERTIES AND INTERNAL CONSISTENCIES FOR THE SCO AND WSO

\begin{tabular}{cccccccc}
\hline Scale & Range & Mean & SD & Median & Mode & n & Cronbach \\
\hline CSQ & $15-55$ & 37,29 & 6,62 & 38,00 & 39,00 & 1028 & 0,83 \\
WSQ & $10-45$ & 33,17 & 5,63 & 34,00 & 34,00 & 1029 & 0,8 \\
\hline
\end{tabular}

For both of the new scales, all item total correlations were greater than $r=0,34$. Furthermore, the present authors endorsed Amatea et al. (1986) suggested standards for ensuring maximum discriminatory ability for items on a 5-point response scale. In line with this standard all items in both scales had means within the 2- 4 range and all items had a standard deviation of greater than 0,50 .

\section{Discriminant validity}

Table 4 summarises the various Pearson's correlation coefficients found between the CSQ, WSQ, Organizational Commitment Questionnaire (Mowday et al., 1979) and Job Involvement Questionnaire (Kanunugo, 1982).

\section{TABLE 4}

CORRELATION COEFFICIENTS BETWEEN THE WSQ, CSQ, JIQ1, OCQ2, CsS3

\begin{tabular}{lccccc}
\hline & WSQ & CSQ & JIQ & OCQ & CSS \\
\hline WSQ & 1,00 & - & - & - & - \\
CSQ & $0,49 * *$ & 1,00 & - & - & - \\
JIQ & $0,49 * *$ & $0,57^{* * *}$ & 1,00 & - & - \\
OCQ & $0,40^{* * *}$ & $0,35^{* * *}$ & $0,53^{* * *}$ & 1,00 & - \\
CSS & $0,48^{* * *}$ & $0,84^{* * *}$ & $0,68^{* * *}$ & $0,35^{* * *}$ & 1,00 \\
\hline
\end{tabular}

For the above table * $\mathrm{p}<0,05,{ }^{* *} \mathrm{p}<0,01,{ }^{* * *} \mathrm{p}<0,001,1$ Job Involvement Questionnaire (Kanungo, 1982), 2Organisational Commitment Questionnaire (Mowday et al., 1979), 3Career Salience Scale (Greenhaus, 1971).

For correlations with CSS $n=134$, for all other correlations $n=965$.

It can be seen from the Table 4 that the CSQ and WSQ appear to be sufficiently independent suggesting that career salience and work salience are independent constructs. This correlation is well below Morrow's (1983) indication that $r>0,60$ would infer redundancy between measures. This suggestion is further supported in light of the fact of the marginally stronger correlation found between job involvement and organisational commitment, than was found between career and work salience. In a similar light it may be suggested that discriminant validity is 
not only demonstrated between the CSQ and WSQ, but also between the CSQ, WSQ and the Organizational Commitment Questionnaire and Job Involvement Questionnaire. This inference is further supported when looking at the correlation found between the CSS and JIQ where the correlation clearly indicates redundancy. The CSQ and WSQ have lower correlations with the JIQ than the CSS in addition to as similar low correlations with the OCQ. Hence, it is suggested that some of the effects of redundancy may have been eliminated. These results may be seen as contradictory to those of Roodt $(1997$, p.12) who reported findings indicating no theoretical reason to distinguish between the foci "work", "career", "job", "occupation" and "organisation".

A factor analysis was also completed as a further means of assessing both the CSQ and WSQ's reliability and discriminant validity. An initial principal components analysis of the CSQ and WSQ items together revealed four components with Eigenvalues greater than 1, however, the Scree plot indicated only two components explaining $39 \%(28,7 \%+10,67 \%$ respectively), with further factors adding less than $6 \%$ each. The first two components were then rotated using Varimax rotation. Loadings of greater than 0,30 for this rotation are shown below in Table 5 .

TABle 5

FACTOR ANALYSIS OF THE CSQ AND WSQ ITEMS USING VARIMAX

\begin{tabular}{lcc} 
& ROTATION $(\mathrm{N}=965)$ \\
\hline & $\begin{array}{c}\text { Components } \\
\mathbf{1}\end{array}$ & Components \\
\hline CSQ 1 & 0,61 & \\
CSQ 2 & 0,66 & \\
CSQ 3 & 0,42 & \\
CSQ 4 & 0,39 & 0,37 \\
CSQ 5 & 0,45 & 0,34 \\
CSQ 6 & & \\
CSQ 7 & 0,74 & \\
CSQ 8 & 0,63 & \\
CSQ 9 & 0,63 & \\
CSQ 10 & 0,72 & \\
CSQ 11 & 0,75 & \\
WSQ 1 & & \\
WSQ 2 & & 0,51 \\
WSQ 3 & & 0,48 \\
WSQ 4 & & 0,45 \\
WSQ 5 & & 0,45 \\
WSQ 6 & & 0,59 \\
WSQ 7 & & 0,56 \\
WSQ 8 & & 0,78 \\
WSQ9 & & 0,78 \\
\hline
\end{tabular}

The apparent factor structure and loadings supports the existence of the two scales and their independence. CSQ 6 is the only item which loaded incorrectly and this item stating "I want to work, but do not want a demanding career" may be understood to provide more information on the importance of work ("I want to work") when it is positively endorsed to indicate low career salience. By endorsing the item the test-taker might actually be saying that work is important but a career is not, thus explaining this loading. This item may require rewording, however, it must remembered that this item functions well within the CSQ and this anomaly will only occur if the CSQ and WSQ are used together. Item CSQ5 ("I used to care quite a lot about my career but now other things are more important to me") emerged as loading on both factors although more strongly on the first (and expected) factor. This item may have loaded on both factors due to it being conceivable that if a recent event occurred in the respondent's life, for example having a child, the event could lead to a person reconsidering both the role of a career and current work responsibilities in the light of that event. Despite the potential problems with these two items, the factor analysis supports the independence of the CSQ and WSQ.
The CSQ and WSQ were also factor analysed individually to identify their internal factor structure. In both cases only a single factor was indicated and the explained variances were $37,73 \%$ for CSQ and $39,84 \%$ for WSQ. The CSQ, WSQ, OCQ and JIQ were subjected to a factor analysis to further demonstrate the discriminant validity of the scales. The initial principal components analysis revealed eight components with Eigenvalues of over one, however, four of these explained less than $3,2 \%$ of the variance, while the first four explained between $4,1 \%$ and $25 \%$ of the variance (cumulating to a total $43,3 \%$ ). The scree plot supported the existence of only four components. The components were then rotated using Varimax rotation producing the loadings $(>0,30)$ shown in Table 6 .

TABLE 6

FACTOR ANALYSIS OF THE CSQ, WSQ, JIQ AND OCQ USING VARIMAX

\begin{tabular}{|c|c|c|c|c|}
\hline \multicolumn{5}{|c|}{ ROTATION $(\mathrm{N}=965)$} \\
\hline & \multicolumn{4}{|c|}{ Component } \\
\hline & 1 & 2 & 3 & 4 \\
\hline CSQ 1 & & 0,44 & & 0,46 \\
\hline CSQ 2 & & & & 0,62 \\
\hline CSQ 3 & & & & 0,63 \\
\hline CSQ 4 & & & & 0,55 \\
\hline CSQ 5 & & & & 0,45 \\
\hline CSQ 6 & & & 0,35 & 0,37 \\
\hline CSQ 7 & & 0,37 & & 0,62 \\
\hline CSQ 8 & & & & 0,59 \\
\hline CSQ 9 & & 0,55 & & 0,32 \\
\hline CSQ 10 & & 0,49 & & 0,47 \\
\hline CSQ 11 & & 0,47 & & 0,59 \\
\hline WSQ 1 & & & 0,49 & \\
\hline WSQ 2 & & 0,33 & 0,44 & \\
\hline WSQ 3 & & & 0,44 & \\
\hline WSQ 4 & & & 0,41 & \\
\hline WSQ 5 & & & 0,56 & \\
\hline WSQ 6 & & & 0,52 & \\
\hline WSQ 7 & & & 0,74 & \\
\hline WSQ 8 & & & 0,76 & \\
\hline WSQ9 & & & 0,67 & \\
\hline OCQ 1 & 0,51 & & & \\
\hline OCQ 2 & 0,74 & & & \\
\hline OCQ 3 & 0,48 & & & \\
\hline OCQ 4 & 0,46 & 0,38 & & \\
\hline OCQ 5 & 0,67 & & & \\
\hline OCQ 6 & 0,77 & & & \\
\hline OCQ 7 & 0,45 & & & \\
\hline OCQ 8 & 0,68 & 0,35 & & \\
\hline OCQ 9 & & & & \\
\hline OCQ 10 & 0,75 & & & \\
\hline OCQ 11 & 0,57 & & & \\
\hline OCQ 12 & 0,56 & & & \\
\hline OCQ 13 & 0,66 & & & \\
\hline OCQ 14 & 0,70 & 0,33 & & \\
\hline OCQ 15 & 0,68 & & & \\
\hline JIQ 1 & & 0,57 & & \\
\hline JIQ 2 & & 0,31 & & \\
\hline JIQ 3 & & 0,46 & & \\
\hline JIQ 4 & & 0,77 & & \\
\hline JIQ 5 & & 0,76 & & \\
\hline JIQ 6 & 0,32 & 0,61 & & \\
\hline JIQ 7 & 0,33 & & & \\
\hline JIQ 8 & & 0,66 & & \\
\hline JIQ 9 & & 0,67 & & \\
\hline JIQ 10 & & 0,63 & & \\
\hline
\end{tabular}


Each of the four scales, as shown in Table 6, emerged relatively clearly in terms of their items loading on the correct scales. The WSQ emerged very clearly, while CSQ shared some loadings with JIQ and WSQ. Despite these few cross-loadings, the four scales emerge quite clearly in terms of four respective factors. In conclusion it may be said that there is sufficient support to suggest good discriminant validity.

\section{Convergent Validity}

TABLE 7

CORRELATION COEFFICIENTS BETWEEN THE CSQ, WSQ AND CAREER SALIENCE SCALE

$(\mathrm{N}=129$ FOR CORRELATIONS WITH CSS AND N $=990$ FOR ALL OTHER CORRELATIONS)

\begin{tabular}{lllllll}
\hline & 1 & 2 & 3 & 4 & 5 & 6 \\
\hline 1CSQ & 1,00 & & & & & \\
2WSQ & $0,49 * * *$ & 1,00 & & & & \\
3CSS1 Total & $0,84 * * *$ & $0,48 * * *$ & 1,00 & & \\
4CSS & $0,74 * * *$ & $0,36 * * *$ & $0,84 * * *$ & 1,00 & & \\
Subscale 1 & & & & & \\
5CSS & $0,66 * * *$ & $0,26 * * *$ & $0,80 * * *$ & $0,51 * * *$ & 1,00 \\
Subscale 2 & & & & & \\
6CSS & $0,76 * * *$ & $0,55 * * *$ & $0,88 * * *$ & $0,60 * * *$ & $0,55 * * *$ & 1,00 \\
Subscale 3 & & & & & \\
\hline
\end{tabular}

( $n=129$ for correlations with CSS and $n=990$ for all other correlations)

For the above table * $\mathrm{p}<0.05,{ }^{*} \mathrm{p}<0.01,{ }^{* *}$ p $0<.001,1$ Career Salience Scale (Greenhaus, 1971).

Subscale 1 - Relative Importance of Work and Career

Subscale 2 - Planning and Thinking about Career

Subscale 3 - General Attitudes Towards Work

Table 7 shows a high correlation between the CSS total and CSQ, but the correlation between the CSS total and WSQ is only moderately strong. While the correlation between the CSS total and the CSQ indicates good convergent validity, and the correlation between the CSS total and WSQ indicates moderately low convergent validity, these correlations are less meaningful as a result of the varied content of the CSS subscales. Looking at the relationship between the WSQ and the subscales of the CSS, it is apparent that the relationship between the WSQ and the Relative Importance of Work and Career, and Planning and Thinking about Career subscales is relatively weak. This was largely to be expected as the focus of these two subscales is primarily careers. The correlation between the General Attitudes to Work subscale is slightly stronger, as might also be expected as these items focus more upon work salience. A stronger correlation was unlikely as some of the items in this subscale also focus upon the careers and the satisfaction derived from work roles.

In terms of the CSQ, a strong correlation is evident between this scale and the General Attitudes toward Work and Relative Importance of Work and Career subscale. The relationship between the CSQ and the Planning and Thinking about Career subscale is slightly weaker. This may be expected as the General Attitudes Toward Work and Relative Importance of Work and Career subscales tend to focus more upon careers and their importance, while the Planning and Thinking about Career subscale deals more with planning and thinking about careers in the future (as its title suggests), and thereby indirectly deals with the importance of careers. This relates to the reality that career importance must supersede the need or want to plan a career. Stronger correlations could not have been expected as the content of the CSS is relatively heterogeneous and does not focus exclusively on the importance of careers as the CSQ does. The high correlation between the CSQ and the CSS total is to be expected as, in general, both scales aim to measure the same construct, namely career salience. However, it would seem that in the light of the results presented earlier, the CSS is perhaps a purer and more refined measure of this construct.

\section{Concluding comments}

The present research explored a new conceptualisation and operationalisation of work and career salience. The findings outlined in this paper largely support the present authors' model of career and work salience. In summary, the most important findings of this research were: the independence of the conceptualisation and operationalisation of career salience and work salience; the face and content validity of the WSQ and CSQ; the convergent and discriminant validity of the WSQ and CSQ; and the reliability of the CSQ and WSQ. While the CSQ correlates quite highly with Greenhaus' (1971) CSS indicating a degree of redundancy, the evidence for the independence of the WSQ represents the extraction of an under recognised construct of the salience of work. These results need to be considered within the light of an important limitation, namely, the sample demographics. While the sample included respondents representing the various population groups in a South African workforce, there was a relative under-representation of males, Africans and Indians thereby having a potential limiting effect on the generalisability of the findings to these groups.

Despite this limitation, two key theoretical implications arise from these findings. Firstly, while more recent research attempts have largely discarded Greenhaus' (1971) conceptualisation of career salience, the present research indicates that there is value in Greenhaus' original ideas. Secondly, the present study's most central implication is finding evidence that work salience exists as an independent construct from career salience. These two constructs may play an important role in future research related to key areas in occupational psychology. Notably, further research is needed with these scales including discriminant validity studies with the Protestant Work Ethic Work as Central Life Interest constructs. Furthermore, the nature of the world of work is changing rapidly and the relevance of work and career salience within this changing context is an area rich in potential research opportunities.

\section{REFERENCES}

Allen, S. A. \& Ortlepp, K. (2000). The relationship between jobinduced posttraumatic stress and work-based social support. Journal of Industrial Psychology, 26 (1), 1-5.

Amatea, E. S., Cross, E. G., Clark, J. E. \& Bobby, C. L. (1986). Assessing the work and family role expectations of careerorientated men and women: The Life Role Salience Scales. Journal of Marriage and the Family, 48, 831-838.

Aryee, S. \& Tan, K. (1992). Antecedents and outcomes of career commitment. Journal of Vocational Behavior, 40, 288-305.

Beutell, N. J. \& Greenhaus, J. H. (1982). Interrole conflict among married women: The influence of husband and wife characteristics on conflict and coping behavior. Journal of Vocational Behavior, 21, 99-110.

Blau, J. G. (1985). The measurement and prediction of career commitment. Journal of Occupational Psychology, 58, 277-288.

Blau, G., Paul, A. \& St. John, N. (1993). On developing a general index of work commitment. Journal of Vocational Behavior, 42, 298-314.

Blood, M. (1969). Work values and job satisfaction. Journal of Applied Psychology, 53, 456-459.

Callero, P. L. (1985). Role Identity Science. Social-Identity Salience. Social Psychology Quarterly, 48 (3), 203-215.

Dubin, R. (1956). Industrial workers' worlds: A study of the "Central Life Interests" of industrial workers. Social Problems, 3, 131-142.

Fisher, J. (1987). Ergonomics. In Barling, J., Fullagar, C., \& Bluen, S. (Eds.) Behaviour in organisations, South African perspectives. Johannesburg: Lexicon.

Gorn, G. J. \& Kanungo, R. N. (1980). Job involvement and motivation: Are intrinsically motivated managers more job involved? Organizational Behavior and Human Performance, $26,265-277$. 
Greenhaus, J. H. (1971). An investigation of the role of career salience in vocational behaviour. Journal of Vocational Behavior, 1, 209-216.

Greenhaus, J. H. (1973). A factorial investigation of career salience. Journal of Vocational Behaviour, 3, 95-98.

Greenhaus, J. H. (1987). Career Management. Chicago: Dryden.

Greenhaus, J. H., \& Simon, W. E. (1976). Self-esteem, career salience, and the choice of an ideal occupation. Journal of Vocational Behavior, 8, 51-58.

Greenhaus, J. H., \& Simon, W. E. (1977). Career salience, work values, and vocational indecision. Journal of Vocational Behavior, 10, 104-110.

Greenhaus, J. H.,. \& Sklarew, N.D. (1981). Some sources and consequences of career exploration. Journal of Vocational Behavior, 18, 1-12.

Kabanoff, B. (1980). Work and nonwork: A review of models, methods, and findings. Psychological Bulletin, 88, 60-77.

Kanungo, R. N. (1982). Measurement of job and work involvement. Journal of Applied Psychology, 67 (3), 341-349.

Karim, D. (1997). The relationship between inter-role conflict, career-salience and psychological well-being in men and women. Unpublished honours dissertation, University of Witwatersrand, Johannesburg.

Kreitner, R. \& Kinicki, A. (1995). Organizational Behavior (3rd ed.). Chicago: Irwin.

Lobel, S. A. \& St. Clair, L. (1992). Effects of family responsibilities, gender, and career identity salience on performance outcomes. Academy of Management Journal, 35, 1057-1069.

Lodahl, T. M. \& Kejner, M. (1965). The definition and measurement of job involvement. Journal of Applied Psychology, 49 (1), 24-33.

Marshall, S.J. \& Witjing, J. P. (1982). Dimensionality of women's career orientation. Sex Roles, 8 (2), 135-146.

McGinnis, S. K. \& Morrow, P. C. (1990). Job attitudes among fulland part-time employees. Journal of Vocational Behavior, 36, 82-96.
Morrow, P. C. (1983). Concept redundancy in organizational research: The case of work commitment. Academy of Management Review, 8 (3), 486-500.

Morrow, P. C. (1993). The theory and measurement of work commitment. Greenwich: JAI Press.

Morrow, P. C., Eastman, K. \& McElroy, J. C. (1991). Concept redundancy and rater naivety in organisational research. Journal of Applied Social Psychology, 21 (3), 219-232.

Morrow, P. C. \& Goetz, J. F. Jnr. (1988). Professionalism as a form of work commitment. Journal of Vocational Behavior, 32, 92-111.

Morrow, P. C. \& McElroy, J. (1986). Assessing measures of work commitment. Journal of Occupational Behavior, 7, 139-145

Morrow, P. C. \& Wirth, R. E. (1989). Work commitment among salaried professionals. Journal of Vocational Behavior, 34, 40-56.

Mowday, R. T., Steers, R. M. \& Porter, L. W. (1979). The measurement of Organizational Commitment. Journal of Vocational Behavior, 14, 224-247.

Noe, R. A., Noe, A. W. \& Bachhuber, J. A. (1990). An investigation of the correlates of career motivation. Journal of Vocational Behavior, 37, 340-356.

Roodt, G. (1997). Theoretical and empirical linkages between work-related commitment foci. Journal of Industrial Psychology, 23 (2), 6-13.

Rosenthal, R. \& Rosnow, R. L. (1991). Essentials of behavioral research: Methods and data analysis (2nd ed.). New York: McGraw-Hill.

Shore, T. H., Thornton, G. C. III. \& Shore, L. M. (1990). Distinctiveness of three work attitudes: Job Involvement, Organizational Commitment and Career Salience. Psychological Reports, 57, 851-858.

Stumpf, S. A. \& Lockhart, M..C. (1987). Career exploration: Work-role salience, work preferences, beliefs, and behavior. Journal of Vocational Behavior, 30, 258-269.

Wiener, Y. \& Vardi, Y. (1980). Relationships between job, organisation, and career commitments and work outcomesAn integrative approach. Organizational Behavior and Human Performance, 28, 81-96. 